Article

\title{
An Empirical Analysis of the Factors Affecting the Adoption and Diffusion of GBTS in the Construction Market
}

\author{
Wei Wang ${ }^{1}$, Shoujian Zhang ${ }^{2} \mathbb{D}$, Yikun $\mathrm{Su}^{3, *}$ (i) and Xinyang Deng ${ }^{4}$ \\ 1 School of Management, Harbin Institute of Technology, Harbin 150001, China; 13B910046@hit.edu.cn \\ 2 School of Civil Engineering, Harbin Institute of Technology, Harbin 150001, China; zhangsj@hit.edu.cn \\ 3 School of Civil Engineering, Northeast Forestry University, Harbin 150040, China \\ 4 State Grid Liaoning Electric Power Company Limited Economic Research Institute, Shenyang 110015, China; \\ dengxinyanghit@gmail.com \\ * Correspondence: suyk@nefu.edu.cn
}

Received: 25 February 2019; Accepted: 21 March 2019; Published: 25 March 2019

\begin{abstract}
This study focuses on better development of green buildings. The key to the sustainable development of the construction industry is to popularize and promote the spread of green building technologies (GBTS) in the construction market. This study integrates the technology acceptance model (TAM) and the innovation diffusion theory (IDT) to analyze and construct the theoretical model of developers' GBTS adoption behavior from three dimensions, including the individual factor, product factor and interface factor. This paper discusses the mechanism of GBTS adoption and diffusion in the construction market. The data are collected by questionnaire, and the structural equation model (SEM) is used for empirical analysis. The results show that the developers' perceived usefulness (PU) and perceived ease of use (PEOU) of GBTS, developers' innovativeness and sense of community at the individual level, competitive advantage at the product level, as well as government structural guarantees and relevant stakeholders at the interface level have a significant positive impact on the adoption of GBTS by developers. It is proved that the model can explain the basic path of GBTS adoption by developers, and suggestions to promote the adoption and diffusion of GBTS in China are put forward.
\end{abstract}

Keywords: green building technologies; developing countries; developers; construction market

\section{Introduction}

At present, transitional energy use and environmental pollution are causing a major global sustainable development problem. The construction industry has an important responsibility for this [1]. According to statistics, construction accounts for $40 \%$ and $30 \%$ of energy consumption and greenhouse gas emissions, respectively [2,3]. Based on USEIA 2010 [4], buildings are expected to generate 42.4 billion tonnes of carbon in 2035. The construction industry plays an important role in the economic development of every country in the world [2,5]. However, with the development of the construction industry, the consumption of resources and the pollution of the natural environment have become prominent $[6,7]$. On the one hand, the construction industry consumes a lot of natural resources such as iron and steel [8]. On the other, construction activities produce construction waste, and greenhouse gas emissions also have a variety of impacts on ecological and social environments $[9,10]$. In order to deal with these problems, countries began to explore the construction industry from the traditional building mode to the social, economic and environmental dimensions of coordinated sustainable development [11]. As a way of sustainable building development, green building has been put forward and paid attention to all throughout the world. Scholars 
have carried out extensive research on green building and related areas in order to improve the energy efficiency and environmental sustainability of the whole life cycle of the building [12-17]. Compared with the traditional building mode, green building has important advantages in reducing the consumption of resources and protection $[15,18,19]$. To avoid a lot of natural resources and environmental pollution, green building has become an important plan for future development and for the construction industry [5,20-22]. In order to promote this solution for environmental problems, various environmental impact assessment tools have developed. Right now may forms of building sustainability assessment (BSA) [23-26] and neighborhood sustainability assessment (NSA) [27-30] have been developed on green buildings. Depending on the perfect evaluation system and market mechanism, many green building projects have been produced, the concept of green building is spread, and the sense of existence of green building is deepened, which in turn promotes the maturity of the evaluation system and market mechanism. With people's attention on environmental problems, Green building technologies (GBTS) adoption has played an important role in solving these problems. Research shows that the technology and materials in GBTS can improve the energy saving effect and reduce energy consumption by $24.5 \%$ [31]. For example, the use of green walls and energy-efficient windows can reduce building energy consumption by $14 \%$ and $33.5 \%$, respectively [32]. In addition, the adoption of the GBTS through methods such as solar technology and the optimization of the thermal performance of the building envelope, can enable the developer to gain a better market competitive advantage and attract more consumers [5]. The construction of green building requires the effective combination of GBTS and building construction to maximize the efficiency of natural resources and reduce environmental pollution [5,33,34]. The realization of green building needs the effective adoption and diffusion of GBTS [22,35-37]. Numerous studies have shown that the adoption and diffusion of GBTS can improve the market competitiveness of enterprises, increase the income of enterprises, and that the adoption and diffusion of GBTS is an important way to promote the industrialization and scale development of green building [12,35,38]. GBTS includes solar energy technology, prefabricated assembly technology, green roof technology, heat pump technology and so on and they has been widely recognized in the construction market $[5,38,39]$. GBTS runs through the whole life cycle of the construction project. It is necessary to integrate and apply the related technology and components in the whole process of the design and construction of the construction project. In order to realize the conservation of resources and the protection of the environment, the coordinated sustainable development of economy, society and environment can be realized in an all-round way $[5,14,22,40]$. In recent years, different researchers have also carried out a series of studies on the adoption of GBTS in the whole life cycle of architecture from different countries and different dimensions $[5,12,22,36,38,41,42]$. However, despite the numerous policies in the construction sector to encourage the development of green buildings and the adoption of GBTS, the adoption rate of GBTS is still very low $[38,42,43]$.

Promoting the adoption of GBTS requires the joint participation and close cooperation of many stakeholders in the construction project $[36,38,44]$. Darkos et al. also prove that GBTS adoption requires stakeholders to take different measures to promote GBTS diffusion [12,41,45]. In terms of developers, as Gibb and Iscak (2003) said, "Developers play an important role in innovation and decision-making in the construction industry." [46]. On the one hand, developers influence the decision of construction enterprises and individuals in adopting and implementing innovation [46]. On the other, developers are also key intermediate hubs that directly connect and influence final construction consumers and contractors $[47,48]$. The construction industry itself is dependent on traditional technologies, when lacking the incentive to innovate and adopt new technologies $[49,50]$. The traditional industry culture is characterized by slow response to new changes and slow acceptance, which is attributed to the construction industry $[49,51]$. The conservatism of most construction industries is a barrier to the adoption of GBTS by participants. The completion of green building requires the joint participation and effective cooperation of many participants, such as developers, design units, construction units and so on. The developer is the main decision-making body to decide whether the construction project 
should be developed or not, and plays a crucial and decisive role in the promotion of green building and the adoption of GBTS.

However, in the Chinese construction market, the application adoption rate of GBTS is relatively low, most developers lack the initiative to adopt GBTS, and many take an evasive attitude towards GBTS for cost and profit reasons. This greatly influences the adoption and promotion of GBTS [36,52]. According to the statistics, green buildings account for less than 0.4 of the total number of buildings in China [53]. The shortage of supply of green buildings by developers is due to the lack of willingness to develop green buildings in most of China [52,54,55]. Most developers in China do not choose green buildings as an investment because they have to consider factors such as risks of GBTS adoption, maintenance of construction projects and costs [56]. Developers play a leading role in the decision of GBTS adoption in construction projects, which determine the choice and investment of GBTS involved in the construction project, and affect the design plan of the designers and the construction method of the contractors, etc. Their adoption intention and behavior directly affect the GBTS adoption intention and behavior of other stakeholders such as the design unit, construction unit and technical supply unit $[12,14,41]$. Therefore, in order to promote the adoption and diffusion of GBTS and better realize the development of green building on a large scale, this paper studies the behavior willingness of developers to adopt GBTS and the relationship between the factors affecting their adoption intention, which plays a crucial and decisive role in the adoption and promotion of GBTS.

According to the above analysis, the adoption and popularization of GBTS is an important way to complete green building and realize the sustainable development of the construction industry. However, at present, the adoption and popularization rate of GBTS is relatively low, which faces many obstacles in the process of adoption [12,13,38,42], and developers play a decisive role in the decision making for the adoption and promotion of GBTS [48,53,57]. At present, the Darko and Chan research team points out that the adoption of GBTS in developing countries needs better research and investigation $[41,43,45]$. In order to supplement and perfect the relevant research, this paper takes the developers who play a key role in guiding decision making in the process of adopting GBTS as the research object. Considering the innovative basic characteristics of GBTS, this paper introduces the Technology acceptance model (TAM) and Innovation diffusion theory (IDT). Based on the consideration of the individual factors of the developers, the GBTS is extended according to its characteristics, and the Structural equation mode (SEM), is adopted. The method of SEM is an empirical study and analysis on the relationship between the factors influencing developers' adoption behavior of GBTS. From the perspective of developers in developing countries, the research on green building can be supplemented, which can perfect the applied research of GBTS by other scholars. In view of the decision-making key role of developers, its research can promote the improved adoption and diffusion of GBTS.

The rest of the paper consists of five parts. The second section is based on the theory of TAM and IDT to summarize the theoretical basis and put forward the relevant complete research hypothesis. The third part is the empirical research design of GBTS adoption and diffusion behavior based on the research hypothesis, including the design of the scale and data collection. The fourth part carries on the data analysis to the research result. In the fifth section, the results of statistical analysis are analyzed and discussed in detail, and the relevant measures to promote the adoption and promotion of GBTS by developers are given. The sixth part points out the conclusion and significance of the research.

\section{Theoretical Basis and Research Hypotheses}

\subsection{GBTS}

GBTS is an important way to realize the sustainable development of construction industry. At present, many scholars have studied green building and GBTS in many different countries and regions $[5,13,41,43,58]$, and introduced a series of related measures to encourage construction enterprises to actively adopt GBTS [5,12,22,59]. Furthermore, the research team based on Darko 
and Chan has carried out multi-angle, multi-agent and multi-scope research on the adoption of references $[5,13,41-43,58]$. Therefore, the basic definition of GBTS in this study mainly refers to a series of findings of Darko and Chans team on GBTS, and is in accordance with China's green building standards [60]. The final definition of GBTS in this paper is: In the construction industry, it is the general term of the products, measures, processes and technical means to be employed to accomplish the aim of "energy saving, water saving, land saving, material saving and environmental protection" during the whole life cycle of the construction project.

\subsection{Theoretical Basis}

\subsubsection{TAM}

The concept of the Technology Acceptance Model (TAM) dates back to 1975. By studying the relationship between human Behavioral Beliefs, Normative Beliefs and Actual Behavior, Ajzen put forward the Theory of Reasoned Action (TRA) [61,62]. In 1985, Ajzen discovered that there was a key factor in Control Beliefs in the process of human behavior decision-making. He introduced elements of Perceived Behavior Control on the basis of TRA theory. Finally, the Theory of Planned Behavior (TPB) was put forward and summarized [63]. In 1989, Davis introduced TRA and TPB to the field of information system to study the user's acceptance of information technology. The TAM was put forward during the period through the improvement and combination of the two theories [64]. Davis extracted the Perceived Usefulness (PU) from the construction use of Perceived Use-performance in the Schultz and Slevin [65] expectation theory model, and derives a Perceived Ease of Use (PEOU) from the structure of the self-efficacy theory of Bandura [66]. The development of the technology acceptance model (TAM) which is based on the TRA and TPB, and can been seen in Figures 1-3 [63,64,67]. At present, the research on technology adoption behavior mainly uses the Theory of Reasoned Action (TRA), Theory of Planned Behavior (TPB), Technology Acceptance Theory (TAM) and so on. TAM is derived from TRA and TPB models. TRA and TPB are used to explain the universal model of individual behavior, while TRA focuses on the evolutionary analysis of technology adoption behavior. At present, TRA, TPB and TAM are widely used in the research of technology adoption.

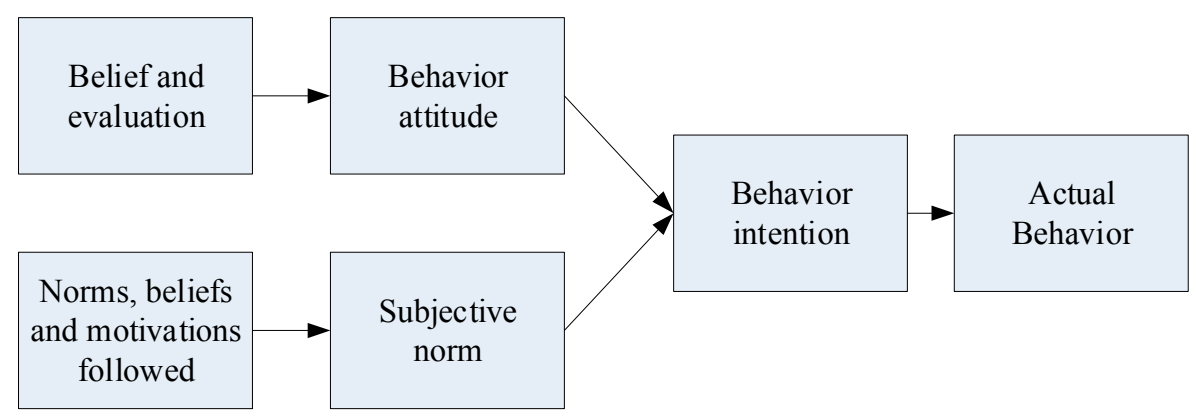

Figure 1. Theory of Reasoned Action (TRA).

In the TAM, the system design characteristic variable is whether people decide to use the external initial variable of the information system, and directly influence the two factors of perceived usefulness and perceived ease of usefulness. Then, in combination with the perceived usefulness, while the user's attitude to use the information system is dependent on the degree of the individual's perceived usefulness and the degree of perceived ease of use, the actual use of the system ultimately depends on the individual's attitude of use. Due to its simple structure and strong explanatory power, the TAM has become one of the best theories in the field of information technology management, and its accuracy has been verified in many fields [68]. Through empirical research, it has been found that the TAM has good adaptability and scientific use; as long as it is properly corrected and expanded, it can be used to explain and predict the process of new technology adoption in other technical or disciplinary backgrounds. The TAM can still show good fit and stability $[69,70]$. At present, the research of 
the whole TAM is more and more subject to cross-discipline, and the trend of combining with the new theory.

Numerous scholars have cited the TAM model in different fields and made a great deal of empirical research on the use of science and technology products [71,72]. It has been proved that TAM has great potential in many research fields [68,73]. TAM is also widely used in the field of construction [74,75], where it is mostly used as the theoretical basis for evaluating whether new imported technologies and paradigms are accepted or not, and the reasons for acceptance or non-acceptance [76,77]. These theories provide a new theoretical perspective for the research of GBTS adoption behavior of developers.

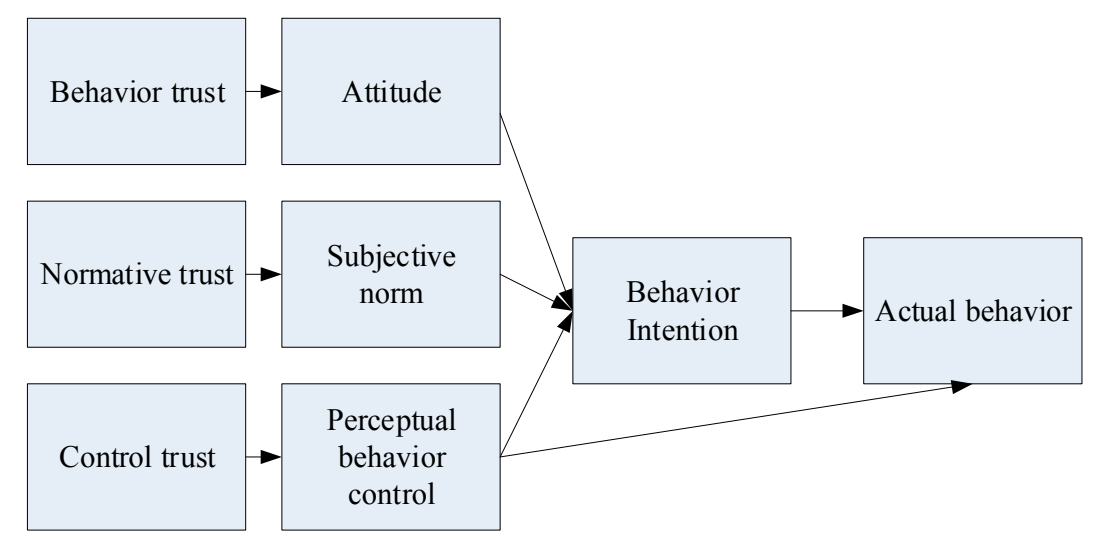

Figure 2. Theory of Planned Behavior (TPB).

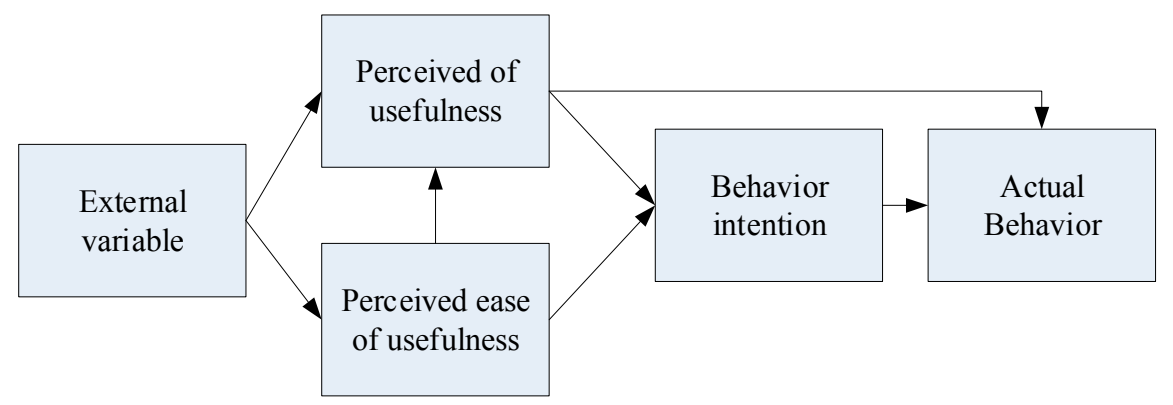

Figure 3. Technology Acceptance Model (TAM).

\subsubsection{IDT}

The IDT (Innovation Diffusion Theory) was proposed by the famous professor Rogers in 1962, whose core idea is: among members of a social system, through a specific path, over time, a process of disseminating innovative develops [78]. Innovation decision process refers to the subjective attitude of the user to the subject of a new product or technology, considering whether to adopt the innovation, then taking practical action, and making a second confirmation of the behavior. Thus, the innovation decision-making process consists of the following five phases: the knowledge stage, persuasion stage, decision stage, implementation stage, confirmation stage. Innovation diffusion theory is divided into two aspects, one is people's acceptance of innovation, the other is the rate of innovation spread or spread in the crowd after people accept innovation. The acceptance degree or the decision-making process of the innovation is related to the characteristics of the innovation itself, and the innovation of its own characteristics has five aspects, one is the comparative advantage, that is, whether one thinks an innovative thing is more advantageous than the old thing it is replacing, and the second is compatibility, that is, whether the innovative thing is compatible with the value, the experience and the expected demand of the original thing, the third is the complexity, that is, whether the innovative thing is easy for people to understand and easy to use, and the fourth is experimental, that is, the degree of the possibility that the innovation is examined, and the fifth is observability, i.e., the extent to which the innovation results can be seen. IDT mainly focuses on the consideration and analysis of social 
attribute factors. On the basis of communication theory, it analyzes the diffusion process of innovation information or innovation entity between social systems. Diffusion pathways can be divided into two categories: mass media and interpersonal communication. Meanwhile, IDT theory is more inclusive for the research objective $[79,80]$.

TAM is a theoretical model proposed by Davis for information technology acceptance, which is based on the theory of planning behavior. IDT refers to a process in which an innovative technology is finally adopted or applied by individual users or organizations through a certain way of transmission. TAM focuses on technology and user behavior, while IDT focuses more on innovative technology and social behavior. Dishaw believes that the combination of TAM and IDT theory can better explain the behavior of users' acceptance of technology [81].

Compared with the traditional building technology, GBTS has the characteristics of breakthrough innovation and positive externality, so the inherent quality of the developers and the interface between the developers and the GBTS have a special influence on the individual adoption of GBTS. From the technical level, GBTS mainly involves the core technology innovation, while TAM can better explain the impact factors of developers towards GBTS adoption from the technical level. Combined with IDT, its theoretical explanation of social behavior and innovation and diffusion of technology dissemination, TAM provides an analysis perspective of individual factors for developers' adoption behavioral intention of GBTS. For example, it can be used to examine the problem of developers' individual adoption quality matching in innovation cognition and social attribution cognition, and the analysis of interface factors, such as the interface between institutions, organizational support and GBTS. Therefore, when using the combination of TAM and IDT to study the adoption behavior of GBTS by developers, its research value lies not only in using TAM to explain the path of adoption behavior of GBTS, but also in explaining the improvement path of supporting system of GBTS diffusion by IDT.

Due to the diversity of the research and the trend of the development of cross-domain, TAM has been accepted by more and more scholars in different fields, and the study of the whole TAM presents a multi-disciplinary cross-cutting, and is constantly combined with the new theory. Based on the initial research of TRA and TPB, new theoretical achievements have been introduced, such as the use and satisfaction theory, innovation diffusion theory, and the usability theory to continuously modify and improve the TAM. The basic idea of IDT and TAM is shown in Figure 4.

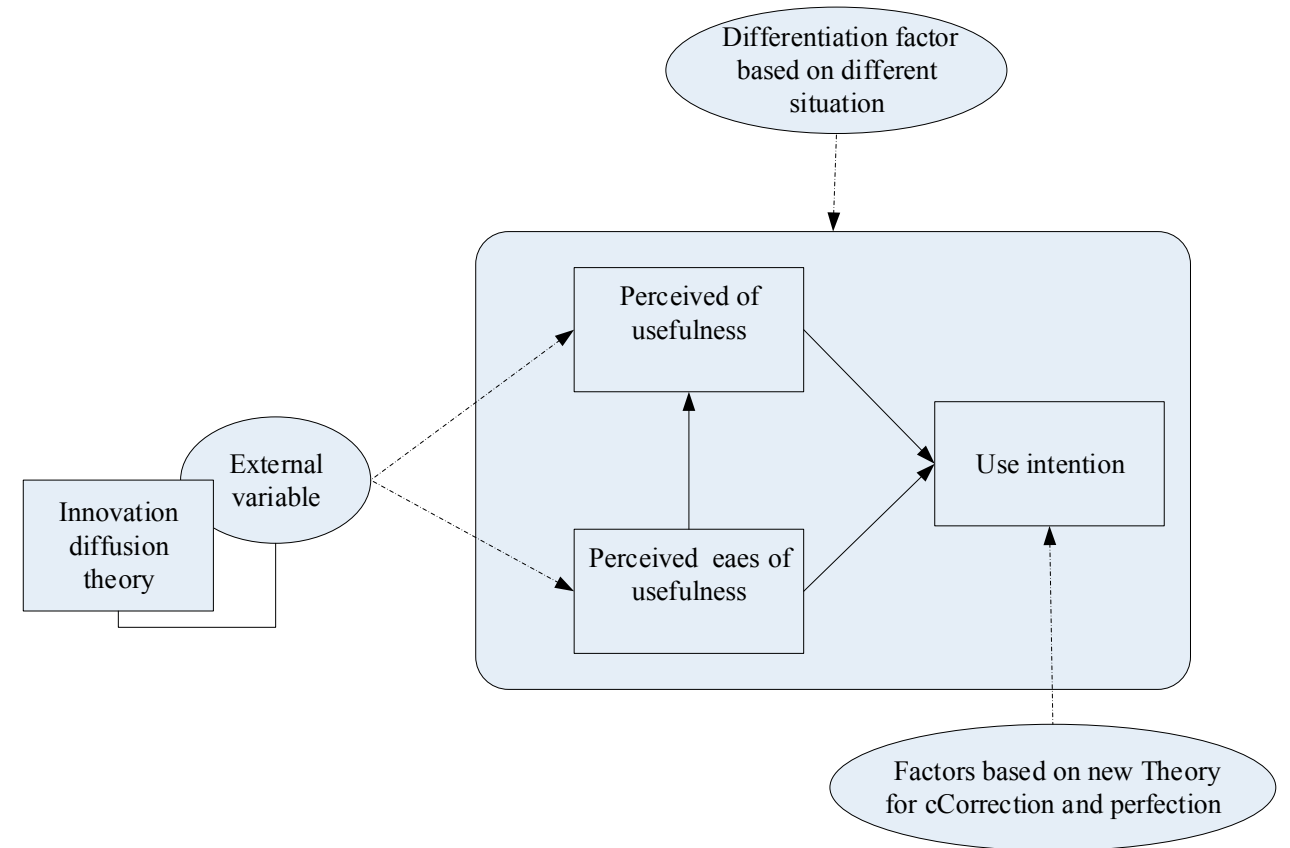

Figure 4. Expansion of TAM (Technology acceptance Model) combined with IDT (Innovation Diffusion Theory). 


\subsection{Research Hypotheses}

\subsubsection{Theoretical Hypotheses Based on TAM}

The basic point of the TAM model is that the motivation of technology acceptance depends mainly on the individual recipient's perceived usefulness (PU) and perceived ease of use (PEOU) of the technology [64]. With the increasingly prominent problems of energy consumption and environmental pollution in the construction industry, the attention of the public to the environmental problems brought by the construction industry has gradually increased, and green building has become an important way of developing energy conservation and environmental protection in the construction industry. GBTS supporting the realization of green building is an important means to realize the sustainable development of the construction industry [5,12]. However, there are barriers due to GBTS being different from traditional building technology, especially in terms of the complexity of technology and the high cost of adoption [42]. It is necessary for developers to make adjustments and extra efforts in the process of adopting and applying GBTS, which is different from the traditional building technology. In the context of technology innovation adopted by GBTS, the PU of this paper refers to the extent to which developers feel that the use of GBTS will improve the developers' development of green buildings, corporate reputation and market competitiveness. PEOU measures how simple it is for developers to adopt GBTS. Previous studies have demonstrated PU and PEOU influence the behavioral intention of users' adoption of technology [68,74,75]. Besides, PEOU affects PU directly $[64,68]$. Therefore, based on the above basic theory, we propose the following hypotheses:

Hypothesis 1. (H1). Developers' PU positively affects their GBTS adoption intentions;

Hypothesis 2. (H2). Developers' PEOU positively affects their GBTS adoption intentions;

Hypothesis 3. (H3). Developers' PEOU of GBTS positively affects PU of GBTS adoption.

2.3.2. Theoretical Hypotheses of Individual Factors Based on IDT

Sense of Community Belonging

According to IDT theory, compatibility is the degree to which perceived innovation and existing values, past experience and potential adopters need to be aligned [82]. This means that the GBTS needs to be consistent with the developers' emotional needs. A sense of community belonging is defined as "an emotional commitment to a place that resides in and is considered to belong to" [83]. This paper uses the sense of community belonging to explain the concept of compatibility, and that sense affects the attitudes of enterprises to environmental protection and social development. The stronger the sense of community belonging is, the more responsible it is for reducing the environmental pollution and promoting the harmonious development of nature and society [52]. As GBTS can reduce energy and material consumption and create a better living environment, developers with a higher sense of community belonging will be more likely to adopt GBTS [53].

This paper is based on the perspective of community regionalism. When developers develop building projects with an external social and environmental impact, as there are individual differences in the sense of community belonging of different developers, developers' cognitive performances of architectural development are also different in the face of construction pollution. As for environmental problems, developers with a strong sense of community belonging tend to show a stronger sense of social responsibility and more active consideration and response to the impact of construction projects on society and the environment, out of a sense of loyalty to the environment. This will affect developers' GBTS adoption behavior decisions. Based on the above analysis, it is concluded that GBTS adoption is driven by the developers' endogenous sense of community belonging. Developers with a strong sense of community belonging will respond positively to the call of the government and social groups for energy conservation and environmental protection measures, and adopt more 
environmentally friendly building technologies to meet their social responsibility and emotional commitment. Therefore, we proposed the hypothesis H4:

Hypothesis 4. (H4). Sense of community belonging positively affects developers' PU for GBTS.

Developers' Innovativeness

Individual Innovativeness is an important research index in IDT. Studies have shown that the early masses with strong communication initiative and individual innovation are vulnerable to corporate marketing efforts [82]. Individuals with strong innovative ideas can quickly discover the advantages of innovative products [84]. When individuals consume green products with the characteristics of environmental protection and innovation, individual innovation significantly influences their behavior [85].

As innovative technologies, GBTS have new functional characteristics, which will attract more attention in the field of architecture. In this case, new architectural style will change. Research has shown that the innovation of the construction industry is a demand-driven phenomenon to some extent because of its unique nature of project dispersion, which is different from the innovation development of other industries $[82,86,87]$. This means that the successful implementation of GBTS, in the construction industry requires the demand of developers to promote the adoption and popularization of GBTS under the conditions of market and customer demand $[88,89]$. As a consumer of GBTS, developers' innovativeness will affect their initiative to adopt GBTS [82,90]. Based on the above research, we infer that the adoption behavior of GBTS technology is often driven by the innovative quality of developers. Therefore, we proposed the hypothesis H5:

Hypothesis 5. (H5.) Developers' Innovativeness positively affects developers' PU to GBTS.

2.3.3. Theoretical Hypotheses of Product Factors Based on LCC

Competitive Advantage

Competitive advantage means that innovative products or technologies have more advantages in terms of cost-effectiveness and convenience than traditional products or technologies of the same kind. Tornatzkyy and Klein found that competitive advantage is the main factor influencing individual adoption in their research on innovation [91]. The whole life cycle cost (LCC) is the sum of the cost of a certain equipment from research and development being put into use at the final disposal stage.

The adoption of GBTS involves the entire life cycle of the building, including design, construction and operation [31,92]. Generally, developers think that the initial cost of adopting GBTS is very high, because the incremental cost of the design and construction phase is borne by the developer, and the incremental income of the operation phase is undertaken by the occupier. However, most studies have shown that green buildings, as the effective measure to mitigate environmental pollution and resource conservation, can save more than 10 times the initial investment over the life cycle of the building, including efficient use of energy, water and materials, improvement of indoor environmental quality, and minimization of negative impacts on the environment [2,5]. Developers, who actively adopt GBTS can get subsidies from the government, while shaping a good corporate image. For long-term life-cycle considerations, good corporate reputation will also give developers a larger market share. All of these will give developers an effective competitive advantage [57]. The initial input cost of GBTS is likely to be higher than that of traditional construction, but expected premium prices and earnings during operation will offset incremental costs and provide developers with economic benefits [93]. Therefore, if developers think that GBTS can give them comparative advantages such as low energy consumption and environmental protection over traditional building technology according to LCC, they are willing to enhance their adoption intention of GBTS. Therefore, we proposed the hypothesis H6:

Hypothesis 6. (H6.) Competitive advantage positively affects developers' PU for GBTS. 


\subsubsection{Theoretical Hypotheses of Interface Factors Based on IDT}

Government's Structural Guarantee

IDT emphasizes the important role of the Media [82]. Its essence is its catalytic action on innovation and its receptor interface. The government's structural guarantee refers to the transaction guarantee mechanism in the aspects of standards, policies and measures formulated by the government department when developers adopt GBTS, including investment guarantee of basic technology facilities, the law, etc.

At present, there are many kinds of GBTS in China's construction market, and the technical suppliers are different to a great extent. New technology is emerging constantly over time, and most developers have a vague understanding of GBTS. Compared with the traditional construction technology, GBTS has have more uncertainties in the later stages of construction and maintenance. Lack of government demonstration projects, relevant laws and regulations at the national level, and timely matching of relevant technical standards prevents developers from choosing and adopting GBTS. There are similar problems in other developing countries [94,95]. As the development time and the scale of green buildings in the developing countries are in the initial stage, the relevant laws and regulations and other supporting policies are not perfect, and lack of relevant technical standards has hindered the adoption and diffusion of GBTS.

Therefore, when the developers' information on GBTS is not comprehensive, the structural guarantee provided by the government can act as the medium on the interface of the developers' GBTS adoption system, and eliminate the uncertain obstacle to the GBTS adoption by developers. Studies have also shown that structural guarantee can improve developers' initial trust $[3,96]$. Therefore, the government's structural guarantee for GBTS can enrich its adoption information of GBTS, reduce the uncertainty of the following stages, such as construction and operation, improve the confidence of adopting GBTS, and perceive that the adoption of GBTS is very simple. Therefore, we proposed the hypothesis H7:

Hypothesis 7. (H7.) Government's structural guarantee positively affects developers' PEOU of GBTS.

\section{Relevant Stakeholders}

The successful adoption and application of GBTS requires the effective cooperation of all participating units in construction engineering [36,97]. The knowledge, experience and ability of project team members are key to ensuring the effective adoption of GBTS [98-101]. As a new construction method, GBTS is not well understood by many developers in actual construction. Compared with traditional building technology, developers need to consider various risks and uncertainties in the design, construction and later operation stages of GBTS [13,42]. Because of the inherent high cost, instability and other characteristics of construction projects, the adoption of GBTS will increase the risk to developer income [42,43].

The theory in the field of social psychology about the influence of information society holds that when people are in unfamiliar situations, it is difficult to make correct judgments and responses. Thus, they often regard the people around them as the source of reasonable information [102]. Therefore, as one of the main media sources of developers' information, relevant stakeholders can influence the decision of developing GBTS more than traditional mass media. In addition, IDT also points out that in addition to their own decision-making style and technical characteristics, the adoption behavior of users is more affected by the social organization [82]. Therefore, when considering whether to adopt GBTS, developers will take the initiative to obtain the corresponding GBTS information from relevant stakeholders in the construction market (such as technical suppliers, design units, construction units, associations, other developers, etc.) and adopt GBTS according to other relevant stakeholders' behavior. Therefore, other stakeholders' awareness and behavior of active adoption of GBTS, as well as good 
technology adoption ability, can better promote the adoption of GBTS by developers and complete the effective diffusion of GBTS. Therefore, this paper puts forward the hypothesis:

Hypothesis 8. (H8.) Relevant stakeholders are positively influencing developers' PEOU of GBTS.

Based on the above assumptions and analysis, this paper constructs a model of developers' intention to adopt GBTS, as shown in Figure 5.

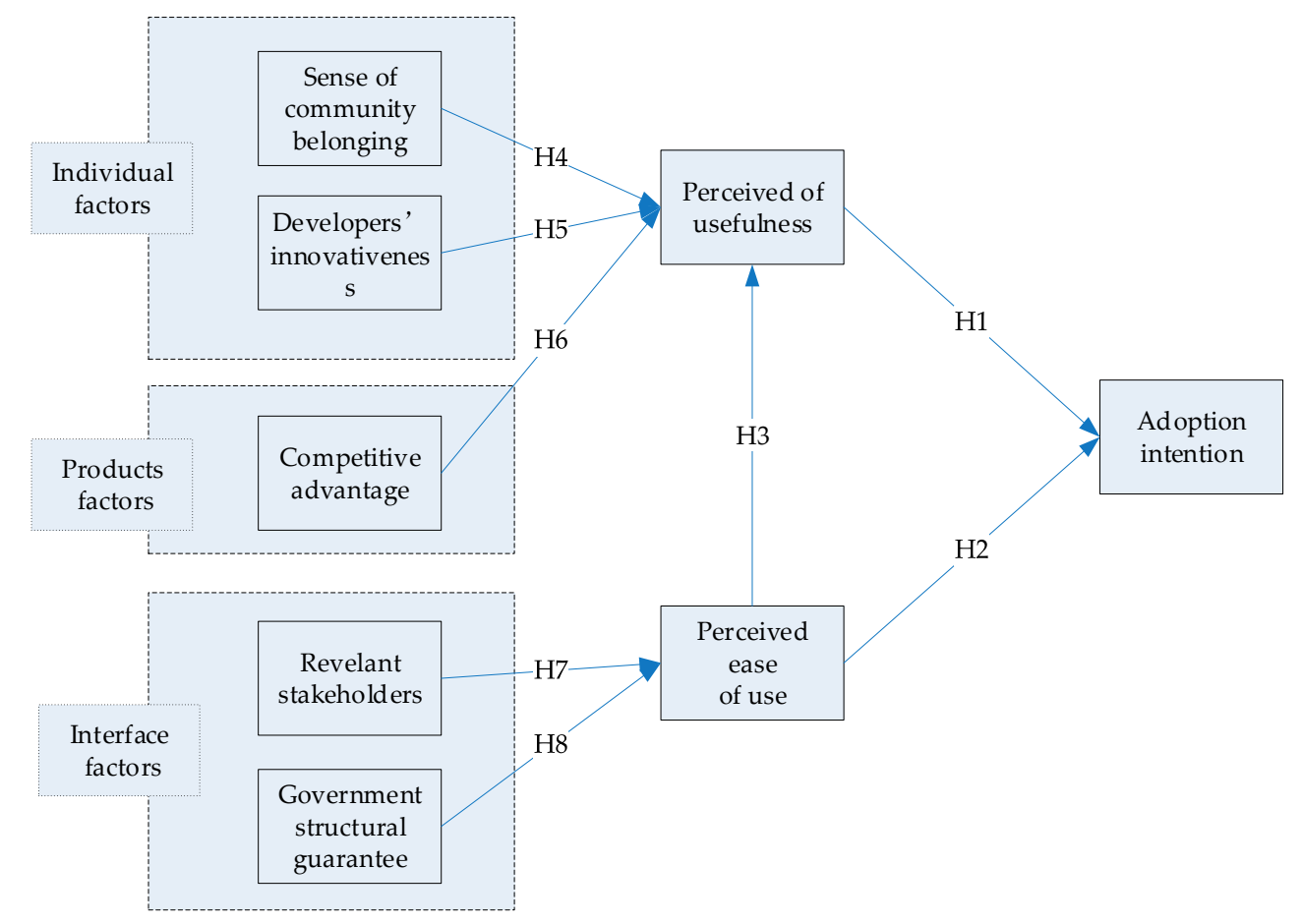

Figure 5. The Research model.

\section{Empirical Study}

\subsection{Questionnaire Design}

In this study, a questionnaire was used as the main measurement method. Based on the existing research results of TAM and IDT, and on the basis of the published classical literature, the questionnaire is discussed repeatedly by the research team, and the relevant experts and scholars are consulted. It is combined with the characteristics of Chinese developers' adoption behavior on GBTS to complete the final design. The final questionnaire can be seen in Appendix A.

\subsection{Data Collection}

In this paper, the questionnaire tests the hypothesis of the constructed model, the objective of the survey is to focus on the developers' staff. After constructing the questionnaire according to TAM and IDT, three university professors and two department managers of developer companies discussed and revised the questionnaire many times. They all have more than 10 years of relevant research or work experience in the construction field. A pilot test of the questionnaire was conducted before the formal survey to ensure the applicability of the expected questions. Because some of the measurements were borrowed from other studies, 17 developer managers were selected to take part in the experiment, and the original questionnaire was revised. They are registered by the Ministry of Housing and Urban-Rural Development (Ministry of Housing and Urban-Rural Development) of the People's Republic of China, with professionals from the China Construction Industry Association (CCIA) and have rich real estate development experience, which ensures the authority and reliability of this study. In order to ensure 
the reliability and effectiveness of the survey, the questionnaire is distributed to the management of the developers' companies. The questionnaire mainly uses a snowball sampling method to increase the number of surveys through the relationship between individuals, which has been shown to be extensive and effective in many studies [48,102]. The questionnaire is aimed at the top 20 developers in China, as they have a monopoly on the market of real estate development projects in China and they are have an absolute advantage in the size of total housing transactions, leading the development direction of China's real estate development. Therefore, the survey can represent the current situation and trend of the development behavior of the developers in China. A total of 400 copies were distributed, 312 copies were returned, and 288 valid questionnaires were obtained. The effective rate of the questionnaire was $72 \%$. The questionnaire used the Likert five-point table, marked in turn with 1-5 which means "very disagreed, disagreed, generally, agreed, very agreed." The survey was conducted between 20 August, 2018 and 18 November, 2018. The final questionnaire consists of two parts, the first part is the basic information of the respondents, the second part is the specific questions adopted by GBTS. The demographic characteristics of the sample can be seen in Table 1.Among the total sample, men accounted for 76.74 percent, while women accounted for 23.36 percent, with the majority of 30-50 years old accounting for 68.75 percent of the total. Postgraduate and graduate are dominant, accounting for $54.17 \%$ and $35.41 \%$, respectively. This shows that the developers surveyed have a higher level of education. The majority of wage earnings are above $6000 \mathrm{RMB}$, accounting for 88.54 percent of the total, indicating higher earnings for Chinese developers.

Table 1. Demographic characteristics of the sample.

\begin{tabular}{cccc}
\hline & Characteristic & Numbers & Percent (\%) \\
\hline \multirow{2}{*}{ Gender } & Male & 221 & 76.74 \\
& Female & 67 & 23.26 \\
\hline \multirow{2}{*}{ Age } & 30 and below & 61 & 21.18 \\
& $31-40$ & 155 & 53.82 \\
& $41-50$ & 43 & 14.93 \\
& 51 and above & 29 & 10.07 \\
\hline \multirow{2}{*}{ Education } & Collage and below & 7 & 2.43 \\
& Graduate & 102 & 35.41 \\
& Postgraduate and above & 156 & 54.17 \\
\hline \multirow{2}{*}{ Average monthly wage income (RMB) } & & 23 & 7.99 \\
\hline & 3000 and below & 0 & 0 \\
& $3001-6000$ & 33 & 11.46 \\
& $6001-9000$ & 166 & 57.64 \\
\hline
\end{tabular}

\section{Research Results}

\subsection{Reliability and Validity Tests}

In this study, Cronach's $\alpha$-coefficient method was adopted to analyze the reliability of the sample data. It is generally considered that when Cronach's $\alpha>0.7$ belongs to the high confidence level and reaches above the 0.5 level, it is considered as the lowest acceptable level reliability standard [103]. The analysis of SPSS software shows that Cronach's $\alpha$ value of each latent variable in this study is obviously greater than 0.7 (see Table 2), which indicates that the model is featured with excellent internal consistency, that is, the scale has passed the reliability test. In order to ensure the follow-up factor analysis of the study data, the KMO test and Barlett's spherical test were carried out with SPSS. The results showed that the KMO value of each potential variable in this study was higher than the minimum standard value of 0.5 (see Table 3) [104]. The total KMO value of this measurement scale is also greater than 0.5. When the significant value is 0.000 , Bartlett's test of sphericity is 2163.148 , which indicates that the correlation matrix is not a unit matrix. In this case, it can be seen that the data in this 
study is suitable for factor analysis [105]. By using SPSS to carry out confirmatory factor analysis, it can be seen from Table 4 that the factor standard load on each measuring index is between 0.61 and 0.94 , and it is more than 0.5 , which indicates that the scale has good convergence validity $[106,107]$.

Table 2. Reliability analysis for each scale.

\begin{tabular}{|c|c|c|c|c|}
\hline Dimension & Constructs & Items & Factor Loading & Cronach's $\alpha$ \\
\hline & \multirow{4}{*}{ Adoption intention } & AI1 & 0.852 & \multirow[t]{4}{*}{0.923} \\
\hline & & AI2 & 0.818 & \\
\hline & & $\mathrm{AI} 3$ & 0.824 & \\
\hline & & $\mathrm{AI} 4$ & 0.822 & \\
\hline \multirow{10}{*}{ TAM } & \multirow[t]{2}{*}{ PU } & PU1 & 0.813 & \multirow[t]{5}{*}{0.889} \\
\hline & & PU2 & 0.739 & \\
\hline & \multirow{7}{*}{ PEOU } & PU3 & 0.741 & \\
\hline & & PU4 & 0.720 & \\
\hline & & PU5 & 0.794 & \\
\hline & & PEOU1 & 0.724 & \multirow[t]{4}{*}{0.889} \\
\hline & & PEOU2 & 0.673 & \\
\hline & & PEOU3 & 0.721 & \\
\hline & & PEOU4 & 0.698 & \\
\hline & & PEOU5 & 0.671 & \\
\hline \multirow{7}{*}{ Individual factor } & \multirow{4}{*}{ Sense of community belonging } & SC1 & 0.853 & \multirow[t]{4}{*}{0.880} \\
\hline & & SC2 & 0.850 & \\
\hline & & SC3 & 0.789 & \\
\hline & & SC4 & 0.758 & \\
\hline & \multirow{3}{*}{ Developers' innovativeness } & DI1 & 0.838 & \multirow[t]{3}{*}{0.899} \\
\hline & & DI2 & 0.820 & \\
\hline & & DI3 & 0.814 & \\
\hline \multirow{3}{*}{ Product factors } & \multirow{3}{*}{ Competitive advantage } & CA1 & 0.762 & \multirow[t]{3}{*}{0.852} \\
\hline & & CA2 & 0.874 & \\
\hline & & CA3 & 0.825 & \\
\hline \multirow{8}{*}{ Interface factors } & \multirow{5}{*}{ Relative stakeholders } & RS1 & 0.850 & \multirow[t]{5}{*}{0.922} \\
\hline & & RS2 & 0.780 & \\
\hline & & RS3 & 0.711 & \\
\hline & & RS4 & 0.787 & \\
\hline & & RS5 & 0.817 & \\
\hline & \multirow{3}{*}{ Government's structural guarantee } & GS1 & 0.730 & \multirow[t]{3}{*}{0.861} \\
\hline & & GS2 & 0.855 & \\
\hline & & GS3 & 0.887 & \\
\hline
\end{tabular}

Table 3. KMO and Bartlett's Test.

\begin{tabular}{ccc}
\hline \multicolumn{2}{c}{ Kaiser-Meyer-Olkin Measure of Sampling Adequacy. } & 0.922 \\
\hline & Approx. Chi-Square & 6393.316 \\
Bartlett's Test of Sphericity & df & 496 \\
& Sig. & 0.000 \\
\hline
\end{tabular}

Table 4. Goodness-of-fit measures of CFA model.

\begin{tabular}{ccccc}
\hline Goodness-of-Fit Measure & Index & Basic Level & Results & Model Fitting Judgment \\
\hline Absolute fit & $\mathrm{x}^{2} / \mathrm{df}$ & $<3$ & 1.370 & Accepted \\
& RMSEA & $<0.08$ & 0.036 & Accepted \\
Incremental fit & CFI & $>0.90$ & 0.973 & Accepted \\
& TLI & $>0.90$ & 0.970 & Accepted \\
& IFI & $>0.90$ & 0.973 & Accepted \\
& NFI & $>0.90$ & 0.908 & Accepted \\
Parsimony-adjusted comparative fit index & PGFI & $>0.50$ & 0.747 & Accepted \\
\hline
\end{tabular}




\subsection{Model Fitting Analysis}

AMOS software is used to validate the sample data. The structural equation model and the maximum likelihood estimation method are adopted to test the theoretical model and hypotheses. Table 4 shows that the comprehensive fitting indexes are in accordance with the evaluation criteria, which indicates that the overall fitting effect of this research model is good and can be used to test the hypothesis.

\subsection{Hypothetical Test Results}

The statistical analysis results are sorted, and the results of each verification are shown in Figure 6. For a simple and clear presentation of the model, the variables involved in the model are abbreviated and the corresponding abbreviations are shown in Table 5. The specific path coefficients of the model are shown in Table 6. Obviously, the hypotheses H1 to H8 hold true. Hypotheses H1 to H8 are confirmed at the 0.001 level, except for H3, which is confirmed at the 0.05 level.

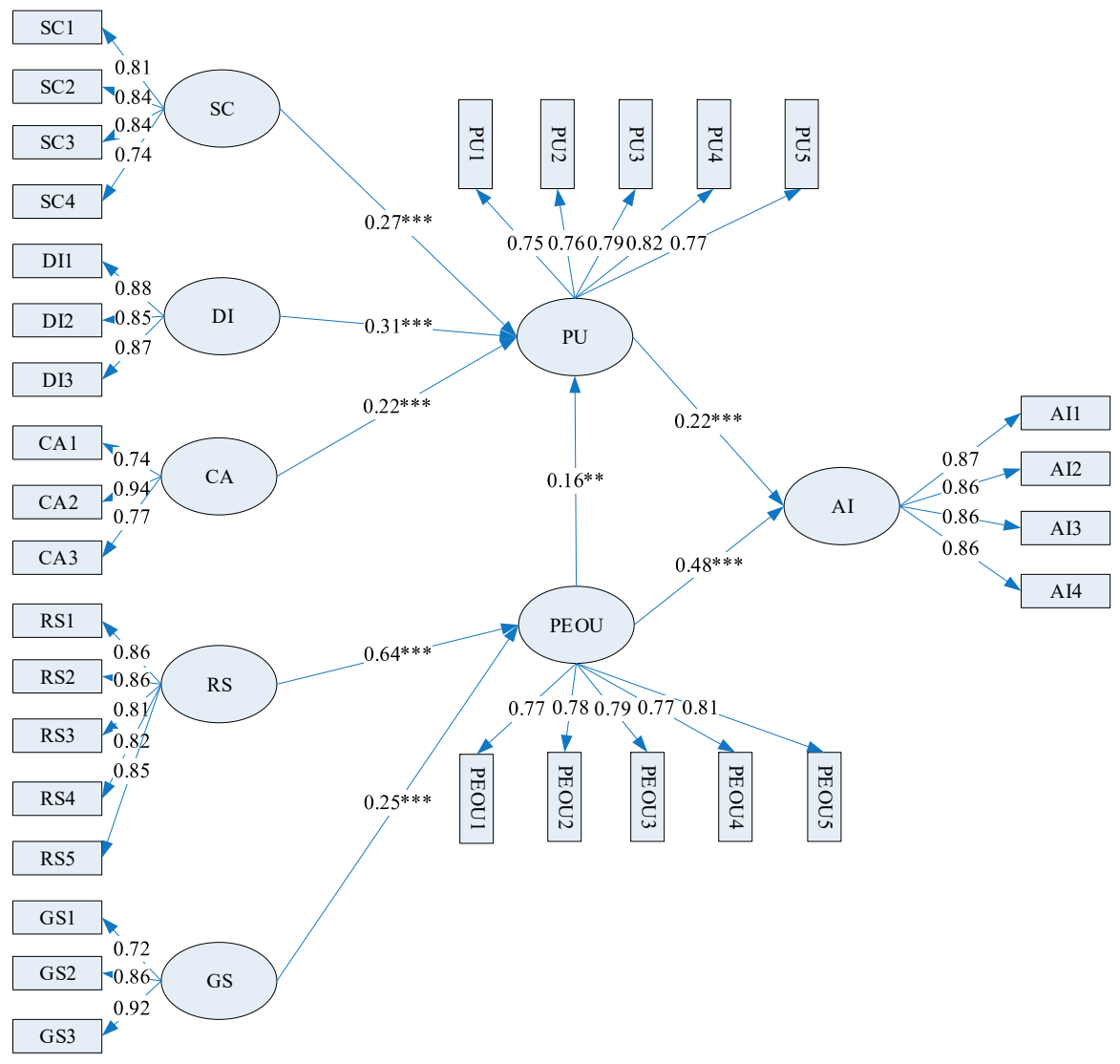

Figure 6. The structural equation model ${ }^{* * *} p$-value is less than $0.001 ;{ }^{* *} p$-value is less than 0.01 .

Table 5. Glossary of abbreviations.

\begin{tabular}{ccc}
\hline Abbreviations & Constructs & Items \\
\hline AI & Adoption intention & AI1-AI4 \\
PU & Motivation & PU1-PI3 \\
PEOU & GBTS capability & PEOU1-PEOU3 \\
SC & Sense of community belonging & SC1-SC4 \\
DI & Developers' innovativeness & DI1-DI4 \\
CA & Competitive advantage & CA1-CA4 \\
RS & Relative stakeholders & RS1-RS5 \\
GS & Government's structural & GS1-GS3 \\
& guarantee &
\end{tabular}


Table 6. Unstandardized regression weights.

\begin{tabular}{|c|c|c|c|c|c|c|}
\hline & & & Estimate & S.E. & C.R. & $p$ \\
\hline PEOU & $<-$ & RS & 0.578 & 0.055 & 10.411 & $* * *$ \\
\hline PEOU & $<-$ & GS & 0.265 & 0.057 & 4.667 & $* * *$ \\
\hline PU & $<-$ & SC & 0.253 & 0.060 & 4.210 & $* * *$ \\
\hline PU & $<-$ & DI & 0.281 & 0.060 & 4.704 & $* * *$ \\
\hline PU & $<-$ & PEOU & 0.141 & 0.054 & 2.621 & $0.009^{* *}$ \\
\hline PU & $<-$ & CA & 0.191 & 0.050 & 3.798 & $* * *$ \\
\hline $\mathrm{AI}$ & $<-$ & PU & 0.287 & 0.081 & 3.549 & $* * *$ \\
\hline $\mathrm{AI}$ & $<-$ & PEOU & 0.569 & 0.077 & 7.371 & $* * *$ \\
\hline AI1 & $<-$ & $\mathrm{AI}$ & 1.000 & & & \\
\hline AI2 & $<-$ & $\mathrm{AI}$ & 1.058 & 0.054 & 19.435 & $* * *$ \\
\hline $\mathrm{AI} 3$ & $<-$ & AI & 1.025 & 0.053 & 19.455 & $* * *$ \\
\hline $\mathrm{AI} 4$ & $<-$ & $\mathrm{AI}$ & 0.958 & 0.050 & 19.311 & $* * *$ \\
\hline PU1 & $<-$ & PU & 1.000 & & & \\
\hline PU2 & $<-$ & PU & 1.017 & 0.079 & 12.898 & $* * *$ \\
\hline PU3 & $<-$ & PU & 1.175 & 0.087 & 13.479 & $* * *$ \\
\hline PU4 & $<-$ & PU & 1.092 & 0.078 & 13.962 & $* * *$ \\
\hline PU5 & $<-$ & PU & 1.067 & 0.082 & 13.048 & $* * *$ \\
\hline PEOU5 & $<-$ & PEOU & 1.000 & & & \\
\hline PEOU4 & $<-$ & PEOU & 0.930 & 0.065 & 14.251 & $* * *$ \\
\hline PEOU3 & $<-$ & PEOU & 0.931 & 0.063 & 14.708 & $* * *$ \\
\hline PEOU2 & $<-$ & PEOU & 0.940 & 0.064 & 14.632 & $* * *$ \\
\hline PEOU1 & $<-$ & PEOU & 0.940 & 0.066 & 14.228 & $* * *$ \\
\hline SC4 & $<-$ & SC & 1.000 & & & \\
\hline SC3 & $<-$ & SC & 1.116 & 0.081 & 13.722 & $* * *$ \\
\hline SC2 & $<-$ & SC & 1.203 & 0.088 & 13.689 & $* * *$ \\
\hline SC1 & $<-$ & SC & 1.043 & 0.078 & 13.343 & $* * *$ \\
\hline DI3 & $<-$ & DI & 1.000 & & & \\
\hline DI2 & $<-$ & DI & 1.138 & 0.063 & 18.090 & $* * *$ \\
\hline DI1 & $<-$ & DI & 1.101 & 0.058 & 18.843 & $* * *$ \\
\hline CA3 & $<-$ & CA & 1.000 & & & \\
\hline CA2 & $<-$ & CA & 1.218 & 0.082 & 14.897 & $* * *$ \\
\hline CA1 & $<-$ & CA & 0.922 & 0.070 & 13.093 & $* * *$ \\
\hline GS3 & $<-$ & GS & 1.000 & & & \\
\hline GS2 & $<-$ & GS & 1.043 & 0.059 & 17.653 & $* * *$ \\
\hline GS1 & $<-$ & GS & 0.870 & 0.062 & 14.098 & $* * *$ \\
\hline RS5 & $<-$ & RS & 1.000 & & & \\
\hline RS4 & $<-$ & RS & 0.943 & 0.055 & 17.081 & $* * *$ \\
\hline RS3 & $<-$ & RS & 0.918 & 0.055 & 16.721 & $* * *$ \\
\hline RS2 & $<-$ & RS & 1.053 & 0.057 & 18.614 & $* * *$ \\
\hline RS1 & $<-$ & RS & 1.030 & 0.056 & 18.435 & $* * *$ \\
\hline
\end{tabular}

\section{Discussion}

The results of this study show that the hypotheses are supported by empirical evidence.

Hypotheses $\mathrm{H} 1$ and $\mathrm{H} 2$ are supported, and they hold under the condition of $p<0.001$. The PU and PEOU of GBTS adoption by developers have a significantly positive impact on the intention of GBTS adoption, and the impact of PEOU is more significant. The standardized path coefficients of PU and PEOU are 0.216 and 0.479 respectively, and they are consistent with the conclusion of the TAM. The result reflected in reality is noteworthy. At present, in the construction market in China, there are many developers, who also perceive the usefulness of GBTS. However, there are still many confusions about the ease of use of GBTS and technology adoption [42]. Therefore, in order to improve the intention of GBTS adoption by developers, it is necessary to improve the ease of use of GBTS by developers, and remove the obstacles encountered by developers in adopting GBTS from many aspects, such as policy guidance support, project demonstration applications, and technical facilities 
matching their stakeholders, and so on $[12,35,38]$. Only by reducing the difficulty of adoption can we improve the adoption and diffusion of GTBS.

Hypothesis H3 that PEOU affects PU is also supported, but does not hold under $p<0.01$ and $p<0.001$, only under $p<0.05$. This means that PEOU has an impact on PU in the basic modeling of TAM, while the effect of PEOU on PU is also true for developers' GBTS adoption behavior. However, there are not significant problems. The result of this is noteworthy. According to the adoption situation and the characteristics of GBTS in China, this conclusion is understandable. The reality is that not all easy GBTS are recognized as useful by developers. At present, there are many problems in the Chinese construction market, so if a large supply of GBTS cannot meet the demand of developers, developers cannot measure and select GBTS [22,59]. Therefore, according to this hypothesis, we should constantly strengthen the integration of green building supply chain, from the supply of GBTS to the selection of applications for integration and coordination $[5,22,59]$.

\subsection{Analysis of Individual Factors}

Developers have obvious individual differences in their views on GBTS, and developers with high innovativeness are more aware of the usefulness of GBTS and are more willing to adopt GBTS. This is consistent with some scholars' view that developers' innovation will affect new building technology $[52,108]$. Innovation inspires individual sources of interest and exploration, which not only means they are more willing to study new things, but also shows that they are more optimistic about risk and more resistant to uncertainty. GBTS as an innovative technology and product, it needs developers take time to understand it, and the uncertainty brought by GBTS also tests the developers' ability to resist risks.

At the same time, developers, who have the stronger sense of community belonging and responsibility for the society and the region are also more likely to adopt GBTS as the technologies are environmentally friendly. In terms of the reality of China's construction industry, developers with high general qualifications, such as Zhonghai Real Estate and Vanke Group generally have a stronger sense of social responsibility and are more likely to adopt GBTS [48,52], which is consistent with the situation in other developing countries. Zainul Abidin [57] pointed out that for many developers in Malaysia, survival is more important than environmental sustainability, and large construction companies tend to understand environmental sustainability better than smaller ones. In China, environmental organizations and media focus on the impact on large enterprises far more than on small and medium-sized enterprises [109]. As a result, China's large construction companies prefer to pay more attention to sustainability when compared with small and medium-sized enterprises, and they also tend to have a better understanding and performance when concerning environmental sustainability than smaller ones $[54,110]$.

The results from the individual factors show that the more innovative the developer is or the stronger the sense of community belonging is, the stronger the willingness to adopt GBTS is. At the same time, in the process of innovation diffusion, it is the adoption from the first group of innovation that plays a key role in the diffusion of new products [38,108]. Therefore, for the promotion and diffusion of GBTS, in the field of construction, it is necessary to demonstrate and promote the GBTS adoption project from large state-owned real estate developers and the large developers of first-grade qualification. Through the GBTS adoption demonstration and the mature technology application demonstration of the public building project, the GBTS adoption of the lower qualification grade developer is popularized and promoted, and the maturity of the GBT application and the market development of GTBS are enhanced gradually. In addition, when GBTS suppliers spread to the market for technology products, they should first lock in "leading customers" as a group of developers, who are innovative or have a strong sense of community belonging, and as a breakthrough in opening up the field of GBTS adoption. The governments should give early publicity and preferential subsidies to these developers, guide them to adopting GBTS as soon as possible and forming demonstration 
projects, and play a positive role in adopting relevant groups in the GBTS market. The influence of GBTS diffusion in the middle and late stages on the construction market should also be considered.

\subsection{Analysis of Product Factors}

From the perspective of product factors, there is a significantly positive correlation between the competitive advantage and the PU of developers. Developers believe that the technological advantages of GBTS can promote the development of enterprises and obtain economic benefits. The competitive advantage will affect the PU perception of GBTS adoption by developers, which is the result of long-term accumulation of GBTS adoption behavior. The adoption of GBTS will bring economic benefits to developers in the whole life cycle, and also bring corporate reputation to developers, which is conducive to the corporate image building and intangible asset obtaining [111,112]. In addition, through the green building labelling scheme coverage and green building labelling scheme publicity, developers have won more consumer attention and market share [31]. These competitive advantages significantly affect the PU of GBTS adoption by developers.

From the product factor perspective, the competitive advantage has positive influence on developers' PU. Developers' better understanding and deeper cognition of the competitive advantages of GBTS can promote their adoption behavior. Therefore, government departments should actively plan and adopt GBTS to form demonstration projects from public buildings, take economic measures such as tax benefits and the reward mechanism to reward developers' adoption behavior [113], improve the relevant regulations, and update technical standards and guidelines at the level of laws and regulations in a timely manner.

\subsection{Analysis of Interface Factors}

From an interface factor perspective, hypothesis $\mathrm{H} 7$ and $\mathrm{H} 8$ are supported. Government structural guarantees have a significant positive impact on the perceived ease of use of developers, that is, the government plays an indispensable role in the adoption and diffusion of GBTS. The introduction of the relevant legal provisions and standard documents led by the government can make it easier for developers to adopt GBTS, and they are more willing to adopt GBTS. Previous studies have proved that government policy guidance and legal standard supervision play important roles in the cognition and initiative of enterprise sustainability [109]. Therefore, improving the government-centered structural support is the important guarantee for developers to enhance the PEOU of GBTS. Besides, developers' GBTS adoption behavior needs detailed strategies and guidance from the local government policies for implementation [114]. At present, China's national and local regulations and policy standards on sustainable construction are not perfect. Many policies involve only macro guidance on sustainability, and when it comes to local policy authorities, the implementation of GBTS is poor [115], which hinders the promotion of GBTS at the local level and on specific projects. Therefore, solving the disconnection between the laws, regulations and standards of China's construction market and the actual implementation of construction projects, and implementing the heterogeneity of policies between central policies and local governments, is also key to promoting the adoption and promotion of GBTS by developers.

Relevant stakeholders also have a significantly positive impact on developers' adoption of GBTS's of PEOU. At present, the adoption rate of GBTS is not high, when there are many obstacles in the adoption, and the relevant publicity is not in place. Other stakeholders in the construction industry chain, such as upstream technology suppliers, contractors, design units, supervision units and other related groups concerning obtaining the common support of the GBTS, are the important medium to ensure the effective adoption and diffusion of GBTS for developers [101]. The uncertainty of GBTS and the lack of information and communication among stakeholders often make developers lack the incentive to adopt GBTS $[116,117]$. Construction products are characterized by high costs and instability. Many projects rely on temporary partnerships. The ultimate beneficiaries of green buildings are consumers, and developers lack the interest and motivation for adopting GBTS [117]. 
For interface factors, governments and enterprises should cooperate for increasing the construction industry chain on GBTS adoption and popularization, and perfecting the structural guarantee system. GBTS suppliers should increase R \& D investment, strive to innovate, highlight the relative advantages of GBTS, and enhance the PU of GBTS adoption by developers. Government should create a good policy environment for the spread of GBTS, which is not only confined to the technical subsidies, but also focuses on enacting the industrial regulation of green buildings and making and enforcing more concrete and reasonable laws, systems and industry development strategies. The adoption of GBTS also needs some supporting facilities, such as green materials and green equipment. In order to fundamentally alleviate the risk-foresight worries of developers about GBTS adoption, governments and stakeholders should continue to enhance the structural security system and the green building supply chain. Therefore, in order to promote GBTS, it is necessary to establish a more complete long-term cooperative relationship among construction stakeholders, strengthen the integration of the green building chain, and improve the green building market $[5,41]$. From the social public level, we should increase consumers' demand for green buildings, strengthen the integration of the demand of material suppliers, technology suppliers and developers, enrich the green design knowledge of design units and improve the green construction ability of construction units.

\section{Conclusions}

GBTS play an important role in realizing green building and promoting sustainable development of the construction industry. However, at present, there are still many obstacles in the adoption and diffusion of GBTS, and the adoption rate is not high in the construction market. Developers play a key role in the adoption and diffusion of GBTS. Based on the TAM-IDT theory, this study puts forward the external theoretical hypotheses of the individual factor, interface factor and product factor on the basis of the literature research of GBTS, which provides a scientific basis for the analysis of the adoption and diffusion of GBTS by developers. The combination of TAM and ITD can not only reveal the regular pattern of GBTS diffusion from the aspect of social communication, but also explores the influence path from the technical aspects. Therefore, it is a perfect and thorough study on the adoption and diffusion of GBTS construction market for analyzing the influence mechanism of the GBTS adoption intention through the three levels of "individual-product-interface". Considering the policy implications, in order to promote the transformation of the construction industry, the development of GBTS should be taken into account. Government departments should improve laws and regulations to ensure the adoption of GBTS, provide technical support and education to improve developers' capacity. In addition, government should also recommend the market-oriented development of GBTS, encouraging developers towards voluntary behavior awareness on GBTS adoption. In this case, a new theoretical perspective is provided for better understanding of the regular pattern and path. Analyzing the adoption behavior of GBT from the point of view of the developer is helpful to better understand the factors that influence GBTS adoption and diffusion, and to facilitate the promotion of GBTS in the field of construction. The research and development of the model also provides a new research method for other related disciplines in the future. This study selected the top 20 developers in China, representing a sample of the overall development trend of Chinese developers. However, there are also some small and medium-sized developers in the Chinese market who are at the bottom of the list. In order to understand the application of GBTS in the whole country, it is found that it is necessary to expand the scope of investigation in the future. Although the influence factors have been explored, there is not much research on the specific practical measures of each influence path, which can be taken as the focus of the relevant research in the future, paying more attention to the research of GBTS market countermeasures and suggestions. In the future, more research methods such as practical case studies, situational experiments, interviews and so on need to be further used in order to realize the exploratory study of the factors influencing the adoption of behavior by other relevant subjects, to provide a more solid theoretical basis for the development of green building. This study only studies GBTS adoption from the perspective of developers. In order to promote the further adoption and 
diffusion of GBTS, other stakeholders and the network structure of relevant stakeholders are all worthy of studying and exploring in the future.

Author Contributions: This paper was part of W.W.'s research, which provided the originality. S.Z. as her supervisor supervised the research direction and supported the research grant. Y.S. gave advice on analysis tools, research data collection and analysis. X.D. improved the initial draft of the paper's content.

Funding: This research received no external funding.

Acknowledgments: This research was supported by Project of the National Thirteenth Five-Year Research Program of China (2016YFC0701606). This study was partly supported by Research and Application of Intelligent Management and Detection Technology for Expressway Construction based on UAV Technology in Shantou Zhanjiang Expressway Project from Huizhou to Qingyuan. The authors are grateful to people who helped undertake the research and improve this article. We would also like to thank the editors and reviewers of Sustainability for their insightful comments on this research.

Conflicts of Interest: The authors declare no conflict of interest.

\section{Appendix A}

Table A1. Questionnaire used in the survey.

\begin{tabular}{|c|c|c|c|c|c|c|c|}
\hline Dimension & Constructs & Measurement Items & 1 & 2 & 3 & 4 & 5 \\
\hline \multirow{7}{*}{$\begin{array}{l}\text { Individual } \\
\text { factor }\end{array}$} & \multirow{4}{*}{$\begin{array}{l}\text { Sense of community } \\
\text { belonging }\end{array}$} & $\begin{array}{l}\text { I attach great importance to the impact of } \\
\text { construction projects on the social environment. }\end{array}$ & & & & & \\
\hline & & $\begin{array}{l}\text { I often take part in the social activities of nature } \\
\text { and environmental protection in the field } \\
\text { of architecture. }\end{array}$ & & & & & \\
\hline & & $\begin{array}{l}\text { I attach great importance to the impact of the } \\
\text { construction project on the living environment. }\end{array}$ & & & & & \\
\hline & & $\begin{array}{l}\text { I think that construction projects should be in } \\
\text { harmony with the natural environment, and } \\
\text { have a sense of responsibility for it. }\end{array}$ & & & & & \\
\hline & \multirow{3}{*}{$\begin{array}{c}\text { Developers' } \\
\text { Innovativeness }\end{array}$} & $\begin{array}{l}\text { I would be happy to try to adopt GBTS in the } \\
\text { construction project. }\end{array}$ & & & & & \\
\hline & & $\begin{array}{l}\text { I think the GBTS is a great progress compared } \\
\text { to traditional construction technology. }\end{array}$ & & & & & \\
\hline & & $\begin{array}{l}\text { I am happy to accept and adopt GBTS, even } \\
\text { though it takes a lot of time and cost. }\end{array}$ & & & & & \\
\hline \multirow{3}{*}{$\begin{array}{l}\text { Product } \\
\text { factors }\end{array}$} & \multirow{3}{*}{$\begin{array}{l}\text { Competitive } \\
\text { advantage }\end{array}$} & $\begin{array}{l}\text { Adoption of GBTS can improve } \\
\text { enterprise reputation. }\end{array}$ & & & & & \\
\hline & & $\begin{array}{l}\text { Adoption of GBTS can improve the market } \\
\text { competitiveness and expand the market share. }\end{array}$ & & & & & \\
\hline & & $\begin{array}{l}\text { Adoption of GBTS will result in more policy } \\
\text { subsidies and lower enterprise costs. }\end{array}$ & & & & & \\
\hline \multirow{5}{*}{$\begin{array}{l}\text { Interface } \\
\text { factors }\end{array}$} & \multirow{3}{*}{$\begin{array}{l}\text { Government's } \\
\text { structural guarantee }\end{array}$} & $\begin{array}{l}\text { The relevant guiding laws and regulations } \\
\text { adopted by GBTS are sound. }\end{array}$ & & & & & \\
\hline & & $\begin{array}{l}\text { Technical guidelines and standards related to } \\
\text { GBTS are sound. }\end{array}$ & & & & & \\
\hline & & $\begin{array}{l}\text { Investment of GBTS related technology and } \\
\text { infrastructure are adequate. }\end{array}$ & & & & & \\
\hline & \multirow{2}{*}{$\begin{array}{l}\text { Relative } \\
\text { stakeholders }\end{array}$} & $\begin{array}{l}\text { Relevant stakeholders will actively provide } \\
\text { technical information to each other during the } \\
\text { adoption of GBTS. }\end{array}$ & & & & & \\
\hline & & $\begin{array}{l}\text { Developers and other stakeholders often hold } \\
\text { technical exchanges activities. }\end{array}$ & & & & & \\
\hline
\end{tabular}


Table A1. Cont.

\begin{tabular}{|c|c|c|c|c|c|c|c|}
\hline Dimension & Constructs & Measurement Items & 1 & 2 & 3 & 4 & 5 \\
\hline & & $\begin{array}{l}\text { The comprehensive evaluation of GBTS by } \\
\text { other stakeholders will affect developers' } \\
\text { adoption decision. }\end{array}$ & & & & & \\
\hline & & $\begin{array}{l}\text { If necessary, relevant stakeholders will try to } \\
\text { cooperate with developers to adopt GBTS. }\end{array}$ & & & & & \\
\hline & & $\begin{array}{l}\text { The conflict caused by the adoption of GBTS in } \\
\text { the construction process of the project can be } \\
\text { solved almost completely and effectively. }\end{array}$ & & & & & \\
\hline \multirow{14}{*}{ TAM } & \multirow{5}{*}{ PU } & $\begin{array}{l}\text { Adoption of GBTS will improve the quality of } \\
\text { the building. }\end{array}$ & & & & & \\
\hline & & $\begin{array}{l}\text { Adoption of GBTS is beneficial to meet the } \\
\text { requirements of energy conservation and } \\
\text { environmental protection for } \\
\text { construction projects. }\end{array}$ & & & & & \\
\hline & & $\begin{array}{l}\text { Adoption of GBTS will increase the business } \\
\text { capacity of developers and expand the market } \\
\text { share of developers. }\end{array}$ & & & & & \\
\hline & & $\begin{array}{l}\text { Adoption of GBTS can reduce environmental } \\
\text { pollution and improve environmental quality. }\end{array}$ & & & & & \\
\hline & & $\begin{array}{l}\text { Adoption of GBTS is conducive to sustainable } \\
\text { development of the construction industry. }\end{array}$ & & & & & \\
\hline & \multirow{5}{*}{ PEOU } & $\begin{array}{l}\text { My interaction with GBTS is clear } \\
\text { and understandable. }\end{array}$ & & & & & \\
\hline & & $\begin{array}{l}\text { I think my understanding of GBTS is clear } \\
\text { and accurate. }\end{array}$ & & & & & \\
\hline & & $\begin{array}{l}\text { I don't think it is complicated to adopt GBTS } \\
\text { technology in the construction project and } \\
\text { complete the project construction. }\end{array}$ & & & & & \\
\hline & & $\begin{array}{l}\text { It's easy for me to choose and adopt } \\
\text { GBTS skillfully. }\end{array}$ & & & & & \\
\hline & & $\begin{array}{l}\text { Adoption of GBTS in construction projects does } \\
\text { not take a lot of time to build. }\end{array}$ & & & & & \\
\hline & \multirow{4}{*}{ Adoption Intention } & $\begin{array}{l}\text { I will recommend the adoption of GBTS to other } \\
\text { interested parties }\end{array}$ & & & & & \\
\hline & & $\begin{array}{l}\text { Whenever possible, I will try to incorporate } \\
\text { GBTS in building development projects }\end{array}$ & & & & & \\
\hline & & $\begin{array}{l}\text { I intend to adopt GBTS regularly and actively in } \\
\text { construction projects }\end{array}$ & & & & & \\
\hline & & $\begin{array}{l}\text { I prefer GBTS to traditional architectural } \\
\text { technology. }\end{array}$ & & & & & \\
\hline
\end{tabular}

\section{References}

1. He, C.C.; Han, Q.; de Vries, B.; Wang, X.M.; Zhao, G.C. Evaluation of sustainable land management in urban area: A case study of Shanghai, China. Ecol. Indic. 2017, 80, 106-113. [CrossRef]

2. Zuo, J.; Zhao, Z.Y. Green building research-current status and future agenda: A review. Renew. Sustain. Energy Rev. 2014, 30, 271-281. [CrossRef]

3. Zhang, X.L. Green real estate development in China: State of art and prospect agenda-A review. Renew. Sustain. Energy Rev. 2015, 47, 1-13. [CrossRef]

4. USEIA. International Energy Outlook 2010; U.S. Energy Information Administration, Office of Integrated Analysis and Forecasting, U.S. Department of Energy: Washington, DC, USA, 2010. 
5. Chan, A.P.C.; Darko, A.; Ameyaw, E.E. Strategies for Promoting Green Building Technologies Adoption in the Construction Industry-An International Study. Sustainability 2017, 9. [CrossRef]

6. Ignatius, J.; Rahman, A.; Yazdani, M.; Saparauskas, J.; Haron, S.H. An Integrated Fuzzy Anp-Qfd Approach for Green Building Assessment. J. Civ. Eng. Manag. 2016, 22, 551-563. [CrossRef]

7. Thomas, C.; Slater, R.; Cox, J. Influencing resourceful behaviours. Resour. Conserv. Recycl. 2013, 79, 1-3. [CrossRef]

8. Li, J.R.; Zuo, J.; Cai, H.; Zillante, G. Construction waste reduction behavior of contractor employees: An extended theory of planned behavior model approach. J. Clean. Prod. 2018, 172, 1399-1408. [CrossRef]

9. Intergovernmental Panel on Climate Change (IPCC). Climate Change 2014: Synthesis Report; IPCC: Geneva, Switzerland, 2014.

10. Sandanayake, M.; Zhang, G.M.; Setunge, S.; Li, C.Q.; Fang, J. Models and method for estimation and comparison of direct emissions in building construction in Australia and a case study. Energy Build. 2016, 126, 128-138. [CrossRef]

11. Gan, X.L.; Zuo, J.; Ye, K.H.; Skitmore, M.; Xiong, B. Why sustainable construction? Why not? An owner's perspective. Habitat Int. 2015, 47, 61-68. [CrossRef]

12. Darko, A.; Chan, A.P.C. Strategies to promote green building technologies adoption in developing countries: The case of Ghana. Build. Environ. 2018, 130, 74-84. [CrossRef]

13. Chan, A.P.C.; Darko, A.; Olanipekun, A.O.; Ameyaw, E.E. Critical barriers to green building technologies adoption in developing countries: The case of Ghana. J. Clean. Prod. 2018, 172, 1067-1079. [CrossRef]

14. Vyas, G.S.; Jha, K.N. Benchmarking green building attributes to achieve cost effectiveness using a data envelopment analysis. Sustain. Cities Soc. 2017, 28, 127-134. [CrossRef]

15. Hwang, B.G.; Zhu, L.; Ming, J.T.T. Factors Affecting Productivity in Green Building Construction Projects: The Case of Singapore. J. Manag. Eng. 2017, 33. [CrossRef]

16. Yuan, Y.P.; Yu, X.P.; Yang, X.J.; Xiao, Y.M.; Xiang, B.; Wang, Y. Bionic building energy efficiency and bionic green architecture: A review. Renew. Sustain. Energy Rev. 2017, 74, 771-787. [CrossRef]

17. Liu, Y.M.; Guo, X.; Hu, F.L. Cost-benefit analysis on green building energy efficiency technology application: A case in China. Energy Build. 2014, 82, 37-46. [CrossRef]

18. World GBC. What Is Green Building? World GBC: London, UK, 1 September 2017.

19. WorldGBC. The Benefits of Green Buildings. Available online: http://www.worldgbc.org/benefits-greenbuildings (accessed on 10 September 2017).

20. United States Green Building Council (USGBC). Building Momentum: National Trends and Prospects for High Performance Green Buildings; USGBC: Washington, DC, USA, 2003.

21. Darko, A.; Zhang, C.Z.; Chan, A.P.C. Drivers for green building: A review of empirical studies. Habitat Int. 2017, 60, 34-49. [CrossRef]

22. Yin, S.; Li, B.Z. Transferring green building technologies from academic research institutes to building enterprises in the development of urban green building: A stochastic differential game approach. Sustain. Cities Soc. 2018, 39, 631-638. [CrossRef]

23. Carvalho, J.P.; Bragança, L.; Mateus, R. Optimising building sustainability assessment using BIM. Autom. Constr. 2019, 102, 170-182. [CrossRef]

24. Mahmoud, S.; Zayed, T.; Fahmy, M. Development of sustainability assessment tool for existing buildings. Sustain. Cities Soc. 2019, 44, 99-119. [CrossRef]

25. Castro, M.d.F.; Mateus, R.; Bragança, L. Development of a healthcare building sustainability assessment method-Proposed structure and system of weights for the Portuguese context. J. Clean. Prod. 2017, 148, 555-570. [CrossRef]

26. Bendewald, M.; Zhai, Z. Using carrying capacity as a baseline for building sustainability assessment. Habitat Int. 2013, 37, 22-32. [CrossRef]

27. Sharifi, A.; Murayama, A. A critical review of seven selected neighborhood sustainability assessment tools. Environ. Impact Assess. Rev. 2013, 38, 73-87. [CrossRef]

28. Sharifi, A.; Murayama, A. Neighborhood sustainability assessment in action: Cross-evaluation of three assessment systems and their cases from the US, the UK, and Japan. Build. Environ. 2014, 72, 243-258. [CrossRef]

29. Moroke, T.; Schoeman, C.; Schoeman, I. Developing a neighbourhood sustainability assessment model: An approach to sustainable urban development. Sustain. Cities Soc. 2019. [CrossRef] 
30. Komeily, A.; Srinivasan, R.S. A need for balanced approach to neighborhood sustainability assessments: A critical review and analysis. Sustain. Cities Soc. 2015, 18, 32-43. [CrossRef]

31. Zhang, X.L.; Shen, L.Y.; Wu, Y.Z. Green strategy for gaining competitive advantage in housing development: A China study. J. Clean. Prod. 2011, 19, 157-167. [CrossRef]

32. Balaras, C.A.; Gaglia, A.G.; Georgopoulou, E.; Mirasgedis, S.; Sarafidis, Y.; Lalas, D.P. European residential buildings and empirical assessment of the Hellenic building stock, energy consumption, emissions and potential energy savings. Build. Environ. 2007, 42, 1298-1314. [CrossRef]

33. Zainul Abidin, N.; Yusof, N.A.; Othman, A.A. Enablers and challenges of a sustainable housing industry in Malaysia. Construct. Innov. 2013, 13, 10-25. [CrossRef]

34. WorldGBC. What Is Green Building? Available online: http://www.worldgbc.org/what-green-building (accessed on 11 September 2017).

35. Johansson, $\mathrm{O}$. The spatial diffusion of green building technologies: The case of Leadership in Energy and Environmental Design (LEED) in the United States. Int. J. Technol. Manag. Sustain. Dev. 2012, 10, 251-266. [CrossRef]

36. Wang, W.; Zhang, S.J.; Su, Y.K.; Deng, X.Y. Key Factors to Green Building Technologies Adoption in Developing Countries: The Perspective of Chinese Designers. Sustainability 2018, 10. [CrossRef]

37. Si, J.; Marjanovic-Halburd, L.; Nasiri, F.; Bell, S. Assessment of building-integrated green technologies: A review and case study on applications of Multi-Criteria Decision Making (MCDM) method. Sustain. Cities Soc. 2016, 27, 106-115. [CrossRef]

38. Koebel, C.T.; Mccoy, A.P.; Sanderford, A.R.; Franck, C.T.; Keefe, M.J. Diffusion of green building technologies in new housing construction. Energy Build. 2015, 97, 175-185. [CrossRef]

39. Sheffer, D.A.; Levitt, R.E. The Diffusion of Energy Saving Technologies in the Building Industry: Structural Barriers and Possible Solutions; Collaboratory for Research on Global Projects; Global Projects Center: Stanford, CA, USA, 2010.

40. Tayyab, A.; Muhammad Jamaluddin, T.; Amad, A. Developing a green-building design approach by selective use of systems and techniques. Architect. Eng. Des. Manag. 2016, 12, 29-50. [CrossRef]

41. Darko, A.; Chan, A.P.C.; Gyamfi, S.; Olanipekun, A.O.; He, B.J.; Yu, Y. Driving forces for green building technologies adoption in the construction industry: Ghanaian perspective. Build. Environ. 2017, 125, $206-215$. [CrossRef]

42. Chan, A.P.C.; Darko, A.; Ameyaw, E.E.; Owusu-Manu, D. Barriers Affecting the Adoption of Green Building Technologies. J. Manag. Eng. 2017, 33. [CrossRef]

43. Darko, A.; Chan, A.P.C.; Yang, Y.; Shan, M.; He, B.J.; Gou, Z.H. Influences of barriers, drivers, and promotion strategies on green building technologies adoption in developing countries: The Ghanaian case. J. Clean. Prod. 2018, 200, 687-703. [CrossRef]

44. Bayraktar, M.E.; Arif, F. Venture Capital Opportunities in Green Building Technologies: A Strategic Analysis for Emerging Entrepreneurial Companies in South Florida and Latin America. J. Manag. Eng. 2013, 29, $79-85$. [CrossRef]

45. Darko, A.; Chan, A.P.C.; Owusu-Manu, D.; Ameyaw, E.E. Drivers for implementing green building technologies: An international survey of experts. J. Clean. Prod. 2017, 145, 386-394. [CrossRef]

46. Gibb, A.; Isack, F. Re-engineering through pre-assembly: Client expectations and drivers. Build. Res. Inf. 2003, 31, 146-160. [CrossRef]

47. Blayse, A.M.; Manley, K. Key influences on construction innovation. Construct. Innov. 2004, 4, $143-154$. [CrossRef]

48. Mao, C.; Shen, Q.P.; Pan, W.; Ye, K.H. Major Barriers to Off-Site Construction: The Developer's Perspective in China. J. Manag. Eng. 2015, 31. [CrossRef]

49. Woudhuysen, J.; Abley, I. Why Is Construction So Backward? Archit. Rev. 2004, 215, 96.

50. Matinaro, V.; Liu, Y. Towards increased innovativeness and sustainability through organizational culture: A case study of a Finnish construction business. J. Clean. Prod. 2017, 142, 3184-3193. [CrossRef]

51. Niu, Y.H.; Lu, W.S.; Liu, D.D.; Chen, K.; Anumba, C.; Huang, G.G. An SCO-Enabled Logistics and Supply Chain-Management System in Construction. J. Constr. Eng. Manag. 2017, 143. [CrossRef]

52. Chang, R.D.; Zuo, J.; Zhao, Z.Y.; Soebarto, V.; Lu, Y.J.; Zillante, G.; Gan, X.L. Sustainability attitude and performance of construction enterprises: A China study. J. Clean. Prod. 2018, 172, 1440-1451. [CrossRef] 
53. He, C.C.; Wang, X.M.; Zhao, G.C. Developer's Willingness to Construct Green Dwellings in China: Factors and Stimulating Policies. J. Civ. Eng. Manag. 2018, 24, 378-389. [CrossRef]

54. Du, P.; Zheng, L.Q.; Xie, B.C.; Mahalingam, A. Barriers to the adoption of energy-saving technologies in the building sector: A survey study of Jing-jin-tang, China. Energy Policy 2014, 75, 206-216. [CrossRef]

55. Zhang, L.; Wu, J.; Liu, H.Y. Turning green into gold: A review on the economics of green buildings. J. Clean. Prod. 2018, 172, 2234-2245. [CrossRef]

56. Jiang, P.; Dong, W.B.; Kung, Y.H.; Geng, Y. Analysing co-benefits of the energy conservation and carbon reduction in China's large commercial buildings. J. Clean. Prod. 2013, 58, 112-120. [CrossRef]

57. Abidin, N.Z. Investigating the awareness and application of sustainable construction concept by Malaysian developers. Habitat Int. 2010, 34, 421-426. [CrossRef]

58. Darko, A.; Chan, A.P.C.; Ameyaw, E.E.; He, B.J.; Olanipekun, A.O. Examining issues influencing green building technologies adoption: The United States green building experts' perspectives. Energy Build. 2017, 144, 320-332. [CrossRef]

59. Yin, S.; Li, B.Z. Matching management of supply and demand of green building technologies based on a novel matching method with intuitionistic fuzzy sets. J. Clean. Prod. 2018, 201, 748-763. [CrossRef]

60. Assessment Standard for Green Building; Ministry of Housing and Urban-Rural Development of China: Beijing, China, 2014.

61. Fishbein, M.A.I.; Belief, A. Intention and Behavior: An Introduction to Theory and Research. Contemp. Sociol. 1975, 6, 1324-1387.

62. Ajzen, I.; Fishbein, M. Understanding Attitudes and Predicting Social Behavior; Prentice-Hall: Upper Saddle River, NJ, USA, 1980.

63. Ajzen, I. From Intention to Actions: A Theory of Planned Behavior. In Action Control: From Cognition to Behavior; Kuhl, J., Bechmand, J., Eds.; Springer: New York, NY, USA, 1985; Volume 26, pp. 894-937.

64. Davis, D.F. Perceived Usefulness, Perceived Ease of Use, and User Acceptance of Information Technology. MIS Q. 1989, 319-340. [CrossRef]

65. Bandura, A. Exercise of Control through Self-Belief-A Citation Classic Commentary on Self-Efficacy-Toward a Unifying Theory of Behavioral-Change by Bandura, A. Curr. Contents/Soc. Behav. Sci. 1989, 14. [CrossRef]

66. Schultz, R.L.; Slevin, D.P.; Pinto, J.K. Strategy and Tactics in a Process Model of Project Implementation. Interfaces 1987, 17, 34-46. [CrossRef]

67. Fishbein, M.; Ajzen, I. Belief, Attitude, Intention, and Behaviour: An Introduction to Theory and Research; Addison-Wesley Pub. Co.: Reading, UK, 1975.

68. Venkatesh, V.; Davis, F.D. A theoretical extension of the technology acceptance model: Four longitudinal field studies. Manag. Sci. 2000, 46. [CrossRef]

69. Szajna, B. Empirical Evaluation of the Revised Technology Acceptance Model. Manag. Sci. 1996, 42, 85-92. [CrossRef]

70. Straub, D.; Keil, M.; Brenner, W. Testing the technology acceptance model across cultures: A three country study. Inf. Manag. 1997, 33, 1-11. [CrossRef]

71. Liao, S.; Shao, Y.P.; Wang, H.; Chen, A. The adoption of virtual banking: An empirical study. Int. J. Inf. Manag. 1999, 19, 63-74. [CrossRef]

72. Verhoef, P.C.; Langerak, F. Possible determinants of consumers' adoption of electronic grocery shopping in the Netherlands. J. Retail. Consum. Serv. 2001, 8, 275-285. [CrossRef]

73. Chen, Y.H.; Barnes, S. Initial trust and online buyer behaviour. Ind. Manag. Data Syst. 2007, 107, $21-36$. [CrossRef]

74. Son, H.; Park, Y.; Kim, C.; Chou, J.S. Toward an understanding of construction professionals' acceptance of mobile computing devices in South Korea: An extension of the technology acceptance model. Autom. Constr. 2012, 28, 82-90. [CrossRef]

75. Liu, D.; Lu, W.; Niu, Y. Extended Technology-Acceptance Model to Make Smart Construction Systems Successful. J. Constr. Eng. Manag. 2018, 144, 04018035. [CrossRef]

76. Son, H.; Lee, S.; Kim, C. What drives the adoption of building information modeling in design organizations? An empirical investigation of the antecedents affecting architects' behavioral intentions. Autom. Constr. 2015, 49, 92-99. [CrossRef] 
77. Lee, S.; Yu, J.; Jeong, D. BIM Acceptance Model in Construction Organizations. J. Manag. Eng. $2015,31$. [CrossRef]

78. Rogers, E.M. Diffusion of Innovations the Free Press of Glencoe. N. Y. 1962, 32, 891-937.

79. Mahler, A.; Rogers, E.M. The diffusion of interactive communication innovations and the critical mass: The adoption of telecommunications services by German banks. Telecommun. Pol 1999, 23, 719-740. [CrossRef]

80. Mahajan, V.; Muller, E.; Bass, F.M. Diffusion of New Products: Empirical Generalizations and Managerial Uses. Mark. Sci. 1995, 14, G79-G88. [CrossRef]

81. Dishaw, M.T.; Strong, D.M. Extending the Technology Acceptance Model with Task-Technology Fit Constructs. Inf. Manag. 1999, 36, 9-21. [CrossRef]

82. Rogers, E.M. The Diffusion of Innovations Model. Diffus. Use Geogr. Inf. Technol. 1993, 70, 9-24. [CrossRef]

83. Hummon, D.M. Community Attachment-Local Sentiment and Sense of Place. Hum. Behav. Environ. Adv. Theory Res. 1992, 12, 253-278. [CrossRef]

84. Citrin, A.V.; Sprott, D.E.; Silverman, S.N.; Stem, D.E. Adoption of Internet shopping: The role of consumer innovativeness. Ind. Manag. Data Syst. 2000, 100, 294-300. [CrossRef]

85. Qi, G.Y.; Shen, L.Y.; Zeng, S.X.; Jorge, O.J. The drivers for contractors' green innovation: An industry perspective. J. Clean. Prod. 2010, 18, 1358-1365. [CrossRef]

86. Aouad, G.; Ozorhon, B.; Abbott, C. Facilitating innovation in construction: Directions and implications for research and policy. Construct. Innov. 2010, 10, 374-394. [CrossRef]

87. Arditi, D.; Kale, S.; Tangkar, M. Innovation in construction equipment and its flow into the construction industry. J. Constr. Eng. Manag. 1997, 123, 371-378. [CrossRef]

88. Kale, S.; Arditi, D. Innovation Diffusion Modeling in the Construction Industry. J. Constr. Eng. Manag. 2010, 136, 329-340. [CrossRef]

89. Nam, C.H.; Tatum, C.B. Leaders and champions for construction innovation. Constr. Manag. Econ. 1997, 15, 259-270. [CrossRef]

90. Swarup, L.; Korkmaz, S.; Riley, D. Project Delivery Metrics for Sustainable, High-Performance Buildings. J. Constr. Eng. Manag. 2011, 137, 1043-1051. [CrossRef]

91. Tornatzky, L.G.; Klein, K.J. Innovation characteristics and innovation adoption-implementation: A meta-analysis of findings. ITEM 1982, EM-29, 28-45. [CrossRef]

92. Wu, H.J.; Yuan, Z.W.; Zhang, L.; Bi, J. Life cycle energy consumption and CO2 emission of an office building in China. Int. J. Life Cycle Assess. 2012, 17, 105-118. [CrossRef]

93. Deng, Y.; $\mathrm{Wu}, \mathrm{J}$. Economic returns to residential green building investment: The developers' perspective. Reg. Sci. Urban Econ. 2014, 47, 35-44. [CrossRef]

94. Milad, S.; Nariman, G.; Reza, E.; Parnaz, O.; Mohd, W.; Mohd, S. The Investigation of the Barriers in Developing Green Building in Malaysia. Mod. Appl. Sci. 2013, 7, 1-10. [CrossRef]

95. Luthra, S.; Kumar, S.; Garg, D.; Haleem, A. Barriers to renewable/sustainable energy technologies adoption: Indian perspective. Renew. Sustain. Energy Rev. 2015, 41, 762-776. [CrossRef]

96. Zhonghua, G.; Stephen Siu-Yu, L.; Deo, P. Market readiness and policy implications for green buildings: Case study from Hong Kong. J. Green. Build. 2013, 8, 162-173. [CrossRef]

97. Mohan, K.; Peter, E.D.L.; Mohammed, D. Integrating procurement and operational innovations for construction industry development. Eng. Constr. Archit. Manag. 2004, 11, 323-334. [CrossRef]

98. Williams, K.; Dair, C. What is stopping sustainable building in England? Barriers experienced by stakeholders in delivering sustainable developments. Sustain. Dev. 2007, 15, 135-147. [CrossRef]

99. Hwang, B.G.; Tan, J.S. Green building project management: Obstacles and solutions for sustainable development. Sustain. Dev. 2012, 20, 335-349. [CrossRef]

100. Hwang, B.G.; Ng, W.J. Project management knowledge and skills for green construction: Overcoming challenges. Int. J. Proj. Manag. 2013, 31, 272-284. [CrossRef]

101. Baron, R.S.; Vandello, J.A.; Brunsman, B. The Forgotten Variable in Conformity Research: Impact of Task Importance on Social Influence. J. Personal. Soc. Psychol. 1996, 71, 915-987. [CrossRef]

102. Lu, S.; Yan, H. An empirical study on incentive of strategic partnering in China: Views from construction companies. Int. J. Proj. Manag. 2007, 25, 241-249. [CrossRef]

103. Nunnally, J.C. Psychometric Theory; McGraw-Hill: New York, NY, USA, 1978. 
104. Norusis, M.J. SPSS 16.0 Statistical Procedures Companion, 2nd ed.; Prentice Hall: Upper Saddle River, NJ, USA, 2008.

105. Yu, J.Y.; He, X.H. Data Statistical Analysis and the SPSS Application; Post \& Telecom Press: Beijing, China, 2003.

106. Hair, J.F.; Black, W.C.; Babin, B.J.; Anderson, R.E. Multivariate Data Analysis; Prentice Hall: Upper Saddle River, NJ, USA, 2009.

107. Akintoye, A. Analysis of factors influencing project cost estimating practice. Constr. Manag. Econ. 2000, 18, 77-89. [CrossRef]

108. Mollaoglu, S.; Chergia, C.; Ergen, E.; Syal, M. Diffusion of green building guidelines as innovation in developing countries. Construct. Innov. 2016, 16, 11-29. [CrossRef]

109. Zeng, S.X.; Meng, X.H.; Zeng, R.C.; Tam, C.M.; Tam, V.W.Y.; Jin, T. How environmental management driving forces affect environmental and economic performance of SMEs: A study in the Northern China district. J. Clean. Prod. 2011, 19, 1426-1437. [CrossRef]

110. Serpell, A.; Kort, J.; Vera, S. Awareness, actions, drivers and barriers of sustainable construction in Chile. Technol. Econ. Dev. Econ. 2013, 19, 272-288. [CrossRef]

111. Xu, J.P.; Wang, Y.; Tao, Z.M. Rough approximation based strategy model between a green building developer and a contractor under a fuzzy environment. Knowl.-Based Syst. 2013, 46, 54-68. [CrossRef]

112. Olubunmi, O.A.; Xia, P.B.; Skitmore, M. Green building incentives: A review. Renew. Sustain. Energy Rev. 2016, 59, 1611-1621. [CrossRef]

113. Varun, P.; Matt, S.; Sinem, K. Adoption of Green Building Guidelines in Developing Countries Based on U.S. and India Experiences. J. Green Build. 2009, 4, 158-174. [CrossRef]

114. Son, H.; Kim, C.; Chong, W.K.; Chou, J.S. Implementing Sustainable Development in the Construction Industry: Constructors' Perspectives in the US and Korea. Sustain. Dev. 2011, 19, 337-347. [CrossRef]

115. Kostka, G.; Moslener, U.; Andreas, J. Barriers to increasing energy efficiency: Evidence from small-and medium-sized enterprises in China. J. Clean. Prod. 2013, 57, 59-68. [CrossRef]

116. Svenfelt, A.; Engstrom, R.; Svane, O. Decreasing energy use in buildings by 50\% by 2050-A backcasting study using stakeholder groups. Technol. Forecast. Soc. Chang. 2011, 78, 785-796. [CrossRef]

117. Berardi, U. Stakeholders' influence on the adoption of energy-saving technologies in Italian homes. Energy Policy 2013, 60, 520-530. [CrossRef]

(C) 2019 by the authors. Licensee MDPI, Basel, Switzerland. This article is an open access article distributed under the terms and conditions of the Creative Commons Attribution (CC BY) license (http:/ / creativecommons.org/licenses/by/4.0/). 